\title{
Warmingiins A and B, Two New Dimeric Naphthoquinone Derivatives from Sinningia warmingii (Gesneriaceae)
}

\author{
Vanessa Winiewski, ${ }^{a}$ Maria Helena Verdan, ${ }^{a}$ Marcos A. Ribeiro, ${ }^{b}$ Alvaro J. \\ Hernandez-Tasco, ${ }^{c}$ Marcos J. Salvador ${ }^{c}$ and Maria Elida A. Stefanello ${ }^{*}$, \\ ${ }^{a}$ Departamento de Química, Universidade Federal do Paraná (UFPR), \\ 81530-900 Curitiba-PR, Brazil \\ ${ }^{b}$ Laboratório de Química de Coordenação, Instituto de Química and ${ }^{c}$ Departamento de Biologia \\ Vegetal, Instituto de Biologia, Universidade Estadual de Campinas (UNICAMP), \\ 13083-970 Campinas-SP, Brazil
}

\begin{abstract}
Chemical investigation of Sinningia warmingii (Gesneriaceae) tubers lead to the isolation of two new dimeric naphthoquinone derivatives, named warmingiins $\mathrm{A}$ and $\mathrm{B}$, besides six known compounds, aggregatin $\mathrm{E}$, aggregatin $\mathrm{F}$, tectoquinone, halleridone, cleroindicin $\mathrm{B}$, and cornoside. All compounds were identified by spectroscopic analysis, mainly nuclear magnetic resonance (NMR) and mass spectrometry (MS), and comparison with the literature. The structure of the warmingiin A, which is an artifact of warmingiin B, was confirmed by X-ray diffraction analysis. Antimicrobial activity of the ethanolic extract and fractions of $S$. warmingii was evaluated against Staphylococcus aureus, S. epidermidis, Escherichia coli, Pseudomonas aeruginosa, Candida albicans, C. dubliniensis, C. glabrata and C. parapsilosis. All samples were inactive.
\end{abstract}

Keywords: Gesneriaceae, Sinningia warmingii, naphthoquinone derivative, antimicrobial evaluation

\section{Introduction}

Sinningia warmingii (Hiern.) Chautems (Gesneriaceae) is a rupicolous or terrestrial herb, with erect stems reaching until $120 \mathrm{~cm}$ and perennial tubers. It is native to South America where is distributed over several countries. In Brazil this plant occurs in Midwest, Southeast and South regions. ${ }^{1,2}$ In Peruvian Amazon S. warmingii is known as "mother potato", and an infusion of its tubers is used to treat gynecological problems, such as puerperal inflammations and microbial vaginosis. ${ }^{3}$ A preliminary phytochemical screening of the tubers detected phenolic glycosides, terpenes, and steroids, ${ }^{3}$ classes of compounds that are widespread in Gesneriaceae family. ${ }^{4}$

Recently we reported the isolation of eight known compounds from $S$. warmingii, which were identified as lapachenole, tectoquinone, 7-methoxytectoquinone, 1-hydroxytectoquinone, 7-hydroxytectoquinone, aggregatin $\mathrm{C}$, aggregatin $\mathrm{D}$ and halleridone. ${ }^{5}$ In continuing

*e-mail: elida@ufpr.br the phytochemical investigation of $S$. warmingii tubers, we report now the isolation of two new dimeric naphthoquinone derivatives, warmingiin A (1) and B (2), together with six known compounds identified by comparison with literature as aggregatin $\mathrm{E}(\mathbf{3}),{ }^{6}$ aggregatin $\mathrm{F}(\mathbf{4}),{ }^{6}$ tectoquinone $(\mathbf{5}),{ }^{7}$ halleridone (6), ${ }^{8}$ cleroindicin B (7),${ }^{9}$ and cornoside $(\mathbf{8}) .{ }^{10}$ Compounds 3, 4, 7 and 8 are being reported for the first time in this species (Figure 1). In addition, antimicrobial activity of the ethanolic extract and fractions obtained by partition with solvents was evaluated.

\section{Experimental}

General experimental procedures

Optical rotations were measured in $\mathrm{CHCl}_{3}$ on a Rudolph Research polarimeter. The UV spectrum was obtained in $\mathrm{MeOH}$ on a Shimadzu UV-2401PC spectrophotometer. Circular dichroism (CD) spectrum was recorded in a Jasco J-815 CD Spectrometer. Nuclear magnetic resonance (NMR) spectra were recorded on Bruker spectrometers 

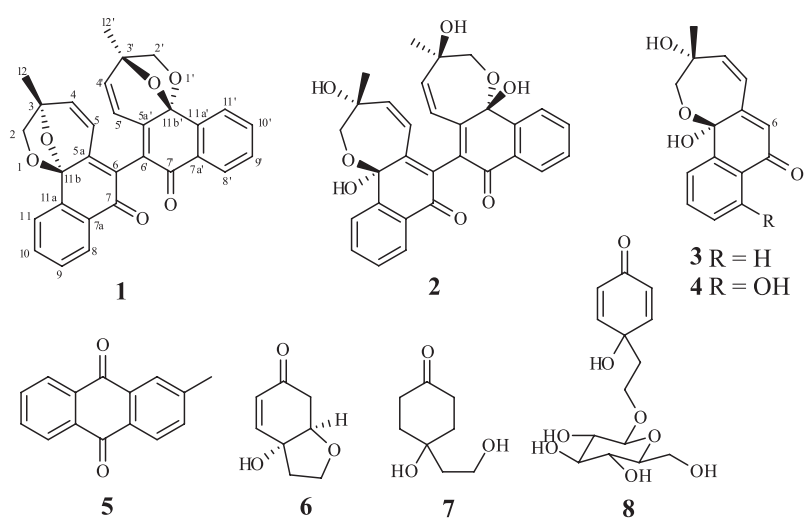

Figure 1. Chemical structures of the compounds 1-8.

(AC 200, Avance 400 and/or Avance 600), observing ${ }^{1} \mathrm{H}$ at 200,400 or $600 \mathrm{MHz}$ and ${ }^{13} \mathrm{C}$ at 50,100 or $150 \mathrm{MHz}$. The solvent used was $\mathrm{CDCl}_{3}$ and the chemical shifts are given in ppm $(\delta)$, using TMS as internal reference, with coupling constants $(J)$ in Hz. High-resolution electrospray ionization mass spectrometry (HRESIMS) data were obtained on a Micromass ESI-Qq Tof mass spectrometer. Highperformance liquid chromatography (HPLC) separations were performed in a Waters apparatus equipped with PDA detector and a semi-preparative Nucleosil 100-5 $\mathrm{C}_{18}$ column $(250 \times 4.6 \mathrm{~mm})$. Silica gel (Merck, 230-400 mesh) was used for column chromatographic separations, while precoated silica gel plates (Macherey-Nagel) were used for thin-layer chromatography (TLC) and preparative TLC (PTLC). Compounds were visualized by exposure under $\mathrm{UV}_{254 / 366}$ light and spraying with $5 \%(\mathrm{v} / \mathrm{v}) \mathrm{H}_{2} \mathrm{SO}_{4}$ in ethanol solution, followed by heating on a hot plate. X-ray data were collected on a Bruker D8 Venture Photon 100 by using graphite-monochromated $\mathrm{Cu} \mathrm{K} \alpha$ radiation $(\lambda=1.5418 \AA)$ at $100(2) \mathrm{K}$. Accurate unit cell dimensions and orientation matrices were determined by least squares refinement of the reflections obtained by $\theta-\chi$ scans. The data were indexed and scaled with the ApexII Suite. ${ }^{11}$ Bruker Saint and Bruker Sadabs were used to integrate and scaling of data, respectively. The structure was solved with Olex $2,{ }^{12}$ using the ShelXT ${ }^{13}$ structure solution program using Direct Methods and refined with the ShelXL ${ }^{14}$ by a full-matrix least-squares technique on $\mathrm{F}^{2}$. All non-hydrogen atoms were refined anisotropically. The hydrogen atoms in the compound were added to the structure in idealized positions and further refined according to the riding model; Olex2 was also used for the drawing of molecular graphics and the preparation of figures for publication.

\section{Plant Material}

Tubers of Sinningia warmingii (Hiern.) Chautems were collected from plants growing wild in Londrina City, Paraná
State, Brazil (2325'32''S, 50²4'50”'W) in May 2012. The plant was identified by Clarice B. Poliquesi, who deposited a voucher specimen in the herbarium of Museu Botânico Municipal (MBM 12804).

\section{Extraction and isolation}

Dried and powdered tubers (61.3 g) were extracted with ethanol $95 \%$ (300 $\mathrm{mL}$ for $24 \mathrm{~h}$, three times) at room temperature. The solvent was removed at reduced pressure using a rotaevaporator. The resulting extract $(2.82 \mathrm{~g})$ was dissolved in EtOH: $\mathrm{H}_{2} \mathrm{O}$ 1:1 $(150 \mathrm{~mL})$ and subjected to partition with hexanes (mixture of isomers), EtOAc and 1-butanol $(3 \times 50 \mathrm{~mL}$, each solvent), successively, giving the respective fractions (A-C) after solvent removal.

Fraction $\mathrm{A}(0.59 \mathrm{~g})$ was submitted to $\mathrm{CC}$ (hexanes:acetone, 9:1 $\rightarrow$ 0:1, and $\mathrm{MeOH})$ yielding 43 fractions $(15 \mathrm{~mL}$ each). After TLC analysis were obtained eleven fractions $\left(A_{1}-A_{11}\right)$. Fraction $A_{4}(15.6 \mathrm{mg}$, eluted with hexanes:acetone 8:2) was purified by HPLC $\left(\mathrm{H}_{2} \mathrm{O}: \mathrm{MeCN} 20: 80\right)$ to give $3\left(\mathrm{R}_{\mathrm{t}}\right.$ (retention time $\left.)=7.83 \mathrm{~min}, 1.6 \mathrm{mg}\right), \mathbf{4}\left(\mathrm{R}_{\mathrm{t}}=8.54 \mathrm{~min}\right.$, $1.5 \mathrm{mg})$, and $5\left(\mathrm{R}_{\mathrm{t}}=10.76 \mathrm{~min}, 0.4 \mathrm{mg}\right) . \mathrm{A}_{8}(48.4 \mathrm{mg}$, eluted with hexanes:acetone 3:2) yielded $\mathbf{1}(6.3 \mathrm{mg})$ and $1+2(4.6 \mathrm{mg})$ after PTLC in $\mathrm{CH}_{2} \mathrm{Cl}_{2}:$ EtOAc 95:5. The mixture $\mathbf{1}+\mathbf{2}$ was purified by HPLC (MeCN $100 \%)$ to give $1\left(\mathrm{R}_{\mathrm{t}}=3.31 \mathrm{~min}, 2.7 \mathrm{mg}\right)$. $\mathrm{A}_{10}(13.0 \mathrm{mg}$, eluted with hexanes:acetone $3: 7)$ was purified by $\mathrm{HPLC}\left(\mathrm{H}_{2} \mathrm{O}: \mathrm{MeOH}\right.$ $62: 38)$ to give $7\left(\mathrm{R}_{\mathrm{t}}=7.59 \mathrm{~min}, 7.1 \mathrm{mg}\right)$.

Fraction B $(0.298 \mathrm{~g})$ was analyzed by ${ }^{1} \mathrm{H}$ NMR revealing almost pure 6 .

Fraction C $(0.198 \mathrm{~g})$ was submitted to $\mathrm{CC}$ (EtOAc: $\mathrm{MeOH}: \mathrm{H}_{2} \mathrm{O}$ 8:1:0.25 $\rightarrow$ 3:6:0.25 and $\mathrm{MeOH}$ ) yielding 36 fractions ( $15 \mathrm{~mL}$ each). After TLC analysis were obtained nine fractions $\left(\mathrm{C}_{1}-\mathrm{C}_{9}\right)$. Fraction $\mathrm{C}_{4}(14.2 \mathrm{mg}$, eluted in EtOAc:MeOH: $\mathrm{H}_{2} \mathrm{O}$ 8:1:0.25) was purified by PTLC in EtOAc: $\mathrm{MeOH}: \mathrm{H}_{2} \mathrm{O}$ 8:1:0.25 to give 7 (1.4 mg). Fraction $\mathrm{C}_{8}\left(23.5 \mathrm{mg}\right.$, eluted in EtOAc: $\mathrm{MeOH}: \mathrm{H}_{2} \mathrm{O}$ 6:3:0.25) yielded cornoside ${ }^{14}(8,3.8 \mathrm{mg})$ after PTLC in EtOAc:MeOH: $\mathrm{H}_{2} \mathrm{O}$ 6:3:0.25.

\section{Antimicrobial assays}

The samples were evaluated for antimicrobial activity applying the microdilution method (96-well plates), as previously described ${ }^{15}$ to give concentrations between 10 to $500 \mu \mathrm{g} \mathrm{mL}^{-1}$. The minimal inhibitory concentration (MIC) was calculated as the lowest concentration showing complete inhibition of the tested strain. In these tests, bacitracin and ketoconazole were used as experimental positive controls for bacteria and fungi strains respectively, while the solution of propyleneglycol/sterile distilled water (5:95, 
v/v) served as the negative control. Each sensitivity test was performed in duplicate for each microorganism evaluated and repeated three times. The strains of bacteria and fungi tested were Escherichia coli ATCC 10799, Pseudomonas aeruginosa ATCC 27853, Staphylococcus aureus ATCC 14458, Staphylococcus epidermidis ATCC 12228, Candida albicans ATCC 10231, Candida glabrata ATCC 30070, Candida dubliniensis ATCC 778157 and Candida parapsilosis ATCC 22019.

\section{Warmingiin A (1)}

Colorless solid; $[\alpha]_{\mathrm{D}}{ }^{20}+50.0(c 0.003, \mathrm{MeOH})$; UV-Vis (MeOH) $\lambda_{\max } / \mathrm{nm}(\log \varepsilon) 206$ (4.0), 218 (3.9), 269 (3.5); $\mathrm{CD}(c 0.01, \mathrm{MeOH}) \lambda_{\max }(\theta) 251(-15.3), 300(+12.6)$, 366 (+4.5); ${ }^{1} \mathrm{H}$ and ${ }^{13} \mathrm{C}$ NMR data, see Table 1; HRESIMS $m / z$, observed: 501.1308; $\mathrm{C}_{30} \mathrm{H}_{22} \mathrm{O}_{6} \mathrm{Na}[\mathrm{M}+\mathrm{Na}]^{+}$requires: 501.1314. Crystallographic data: compound $\mathbf{1}$ was crystallized from acetonitrile by slow solvent evaporation. A colorless block crystal was selected for crystallographic measures. For the supplementary crystallographic data, see Supplementary Information section.

\section{Warmingiin B (2)}

Colorless solid; ${ }^{1} \mathrm{H}$ and ${ }^{13} \mathrm{C}$ NMR data, see Table 1; HRESIMS $m / z$, observed: 513.15641; $\mathrm{C}_{30} \mathrm{H}_{25} \mathrm{O}_{8}[\mathrm{M}-\mathrm{H}]^{-}$ requires: 513.15549 .

\section{Results and Discussion}

Compound 1, named warmingiin A (Figure 1), was isolated as a colorless solid. Its HRESIMS in positive mode displays an ion at $m / z 501.1308[\mathrm{M}+\mathrm{Na}]^{+}$, indicating the molecular formula $\mathrm{C}_{30} \mathrm{H}_{22} \mathrm{O}_{6}$, which is consistent with twenty indices of hydrogen deficiency. In the ${ }^{1} \mathrm{H}$ NMR data, signals of four aromatic protons, in a spin system typical of an aromatic ring 1,2-dissubstituted $\left(\delta_{\mathrm{H}} 7.54-8.10\right)$, two doublets of olefinic protons $\left(\delta_{\mathrm{H}} 6.35\right.$ and $\left.6.45, J 9.7 \mathrm{~Hz}\right)$, two doublets of oxymethylene protons $\left(\delta_{\mathrm{H}} 3.86\right.$ and 3.99 , $J 6.5 \mathrm{~Hz})$, and one singlet of a methyl group $\left(\delta_{\mathrm{H}} 1.71\right)$ were observed (Table 1). These data were very similar to those of aggregatin E (3), previously reported for S. aggregata and also isolated here, but differing mainly for the absence of the signal of H-6. Analysis of heteronuclear single quantum correlation (HSQC) and heteronuclear multiple bond correlation (HMBC) showed 15 different carbons, including a carbonyl group $\left(\delta_{\mathrm{C}} 182.7\right)$, two oxygenated carbons $\left(\delta_{\mathrm{C}} 74.4\right.$ and 80.6) and a dioxygenated carbon $\left(\delta_{\mathrm{C}} 99.5\right)$. Considering the molecular formula, these data indicate a symmetrical dimeric compound. The correlations observed in the HSQC and HMBC spectra (Table 1) are in accordance with structure $\mathbf{1}$. In particular, the position of the linkage between the two moieties was determined by cross-peaks among $\mathrm{H}-5\left(\delta_{\mathrm{H}} 6.35\right)$ and carbons at $\delta_{\mathrm{C}} 80.6$ (C-3), 99.5 (C-11b), 126.4 (C-6) and 147.4 (C-5a). Analysis by X-ray diffraction of a single crystal of $\mathbf{1}$ confirmed the structure and led to assign its absolute configuration as $3 R$, $3^{\prime} R, 11 \mathrm{~b} S, 11^{\prime} \mathrm{b} S$ (Figure 2). The $\mathrm{CD}$ of $\mathbf{1}$ was very similar to that reported for aggregatins $\mathrm{E}(\mathbf{3})$ and $\mathrm{F}(\mathbf{4}),{ }^{6}$ indicating the same absolute configuration (Figure S5).

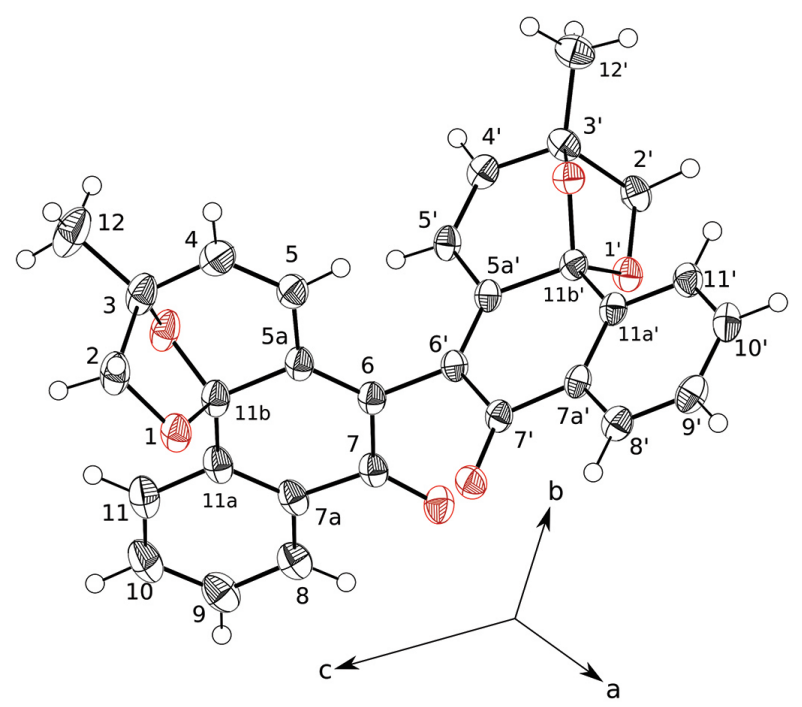

Figure 2. View of assymetric part of unit cell of compound 1. Atomic displacement ellipsoids are at the $50 \%$ level. Hydrogen atoms are represented by open circles

Compound 2, named warmingiin B (Figure 1), was isolated as a colorless solid in admixture with $\mathbf{1}$. Its ${ }^{1} \mathrm{H}$ NMR spectra showed signals in duplicate, with different intensities. The less intense signals were identical to those of $\mathbf{1}$, while the more intense ones were attributed to compound $\mathbf{2}$. These signals indicate that $\mathbf{2}$ has the same groups as in $\mathbf{1}$ (Table 1). The main difference was observed for the chemical shifts of $\mathrm{H}-4 / \mathrm{H}-4$ ' and $\mathrm{H}-5 / \mathrm{H} 5$ ', which had higher chemical shifts in $\mathbf{1}$ than in $\mathbf{2}$. From integrals of $\mathrm{H}-4$ and $\mathrm{H}-5$, the relative proportion of $\mathbf{2}$ and $\mathbf{1}$ was determined as 1:0.7. The HRESIMS spectra in negative mode showed peaks at $\mathrm{m} / \mathrm{z} 477.13517\left([\mathrm{M}-\mathrm{H}]^{-}\right.$, relative to compound 1) and $513.15641\left([\mathrm{M}-\mathrm{H}]^{-}\right.$, relative to compound 2, molecular formula $\mathrm{C}_{30} \mathrm{H}_{25} \mathrm{O}_{8}$ ). All efforts to separate this mixture failed, resulting only in the isolation of 1. After six weeks, a new record of ${ }^{1} \mathrm{H}$ NMR spectra showed that the proportion of $\mathbf{2}$ in the mixture changed from around 60 to $30 \%$. These observations led to the conclusion that 1 was an artifact, formed from 2 by loss of two unities of water during the isolation process. Despite the impossibility of getting compound $\mathbf{2}$ pure, its chemical shifts could be assigned by careful analysis of HSQC and HMBC data (Table 1). The absolute configuration of $\mathbf{2}$ was 
Table 1. NMR data (600 MHz, $\mathrm{CDCl}_{3}$ ) for the compounds $\mathbf{1}$ and $\mathbf{2}$

\begin{tabular}{|c|c|c|c|c|c|}
\hline \multirow{2}{*}{ Position } & \multicolumn{2}{|l|}{1} & \multicolumn{2}{|l|}{2} & \multirow{2}{*}{ HMBC } \\
\hline & $\delta_{\mathrm{H}}(J$ in $\mathrm{Hz})$ & $\delta_{\mathrm{C}}$ & $\delta_{\mathrm{H}}(J$ in $\mathrm{Hz})$ & $\delta_{\mathrm{C}}$ & \\
\hline $2,2^{\prime}$ & $3.86(1 \mathrm{H}, \mathrm{d}, 6.5)$ & 74.4 & $3.86(1 \mathrm{H}, \mathrm{d}, 6.6)$ & 74.2 & 4,12 \\
\hline & $3.99(1 \mathrm{H}, \mathrm{d}, 6.5)$ & & $4.01(1 \mathrm{H}, \mathrm{d}, 6.6)$ & & \\
\hline 3,3 & & 80.6 & & 80.6 & \\
\hline 4,4 & $6.45(1 \mathrm{H}, \mathrm{d}, 9.7)$ & 141.4 & $6.39(1 \mathrm{H}, \mathrm{d}, 9,7)$ & 140.8 & $2,5 \mathrm{a}, 12$ \\
\hline 5,5 & $6.35(1 \mathrm{H}, \mathrm{d}, 9.7)$ & 124.2 & $6.20(1 \mathrm{H}, \mathrm{d}, 9.7)$ & 124.6 & $3,6,12$ \\
\hline $5 \mathrm{a}, 5 \mathrm{a}^{\prime}$ & & 147.4 & & 147.2 & \\
\hline 6,6 & & 126.4 & & 125.8 & \\
\hline $7,7^{\prime}$ & & 182.7 & & 182.2 & \\
\hline $7 \mathrm{a}, 7 \mathrm{a}$ & & 131.3 & & 131.2 & \\
\hline 8,8 & $8.10(1 \mathrm{H}, \mathrm{ddd}, 7.8,1.3,0.8)$ & 126.7 & $8.13(1 \mathrm{H}, \mathrm{ddd}, 7.8,1.2,0.5)$ & 126.6 & $7,10,11 \mathrm{a}$ \\
\hline $9,9^{\prime}$ & $7.54(1 \mathrm{H}, \mathrm{ddd}, 7.8,7.6,1.3)$ & 130.0 & $7.55(1 \mathrm{H}, \mathrm{ddd}, 7.8,7.6,1.3)$ & 129.8 & $7 \mathrm{a}, 11$ \\
\hline $10,10^{\prime}$ & $7.67(1 \mathrm{H}, \mathrm{ddd}, 7.8,7.6,1.3)$ & 133.1 & $7.68(1 \mathrm{H}, \mathrm{ddd}, 7.8,7.6,1.2)$ & 132.9 & $8,11 \mathrm{a}$ \\
\hline $11,11^{\prime}$ & $7.81(1 \mathrm{H}, \mathrm{ddd}, 7.8,1.3,0.8)$ & 126.0 & $7.82(1 \mathrm{H}, \mathrm{ddd}, 7.8,1.3,0.5)$ & 125.8 & $7 \mathrm{a}, 9,12$ \\
\hline 11a, 11a' & & 137.4 & & 137.2 & \\
\hline $11 \mathrm{~b}, 11 \mathrm{~b}$ & & 99.5 & & 99.2 & \\
\hline $12,12^{\prime}$ & $1.71(3 \mathrm{H}, \mathrm{s})$ & 19.2 & $1.70(3 \mathrm{H}, \mathrm{s})$ & 19.3 & $2,3,4$ \\
\hline
\end{tabular}

assigned as $3 R, 3^{\prime} R, 11 \mathrm{~b} R, 11^{\prime} \mathrm{b} R$ by comparison with $\mathbf{1}$, considering a change in the priority order of the groups around $\mathrm{C}-11 \mathrm{~b}$.

Considering the use of $S$. warmingii in folk medicine ${ }^{3}$ ethanolic extract and the fractions obtained by partition were tested for antimicrobial activity against Staphylococcus aureus, S. epidermidis, Escherichia coli, Pseudomonas aeruginosa, Candida albicans, C. dubliniensis, C. glabrata and C. parapsilosis, using the methodology previously reported. ${ }^{15}$ All samples were inactive (MIC $>500 \mu \mathrm{g} \mathrm{mL}^{-1}$ ).

\section{Conclusions}

The new compound $\mathbf{1}$ seems derivate from $\mathbf{2}$ by acid-catalyzed dehydration during isolation process. This reaction is easy, considering the proximity among the hydroxy groups in $\mathbf{2}$. Compound $\mathbf{2}$ is structurally formed by coupling of two unities of aggregatin $E$ (3), a hemiketal with a rare carbon framework. To date three compounds of this type have been reported in the literature, namely aggregatins D-F. All have been isolated for the first time from S. aggregata, ${ }^{6,16}$ and now were found in $S$. warmingii. Aggregatin E also was recently reported in S. allagophylla, ${ }^{17}$ suggesting a close relationship among these three species. Our results of antimicrobial activity did not support the traditional use of $S$. warmingii in infectious diseases. However, this assessment can not be considered final, because chemical composition of this plant may vary along its dispersion area.

\section{Supplementary Information}

Supplementary information (1D and 2D NMR, HRESIMS and CD data) is available free of charge at http://jbcs.sbq.org.br.

Supplementary crystallographic data are deposited at CCDC 1439549. These data can be obtained free of charge from the Cambridge Crystallographic Data Centre (www.ccdc.cam.ac.uk/data_request/cif).

\section{Acknowledgments}

We are grateful to CAPES, FAEPEX-UNICAMP, FAPESP and CNPq for scholarships and financial support, CNPq by authorization for access of samples from the Brazilian genetic heritage (process 010087/2012-5), Clarisse B. Poliquesi, at Museu Botânico Municipal de Curitiba, for collection and identification of the plant, and A. A. Stefanello for English revision.

\section{References}

1. Ferreira, G. E.; Chautems, A.; Waechter, J. L.; Acta Bot. Bras. 2015, 29, 310.

2. Araujo, A. O.; Chautems, A.; Lista de Espécies da Flora do 
Brasil; Instituto de Pesquisas Jardim Botânico do Rio de Janeiro: Rio de Janeiro. Available at http://floradobrasil.jbrj. gov.br/jabot/floradobrasil/FB7935, accessed in April, 2016.

3. Casana, C. F. D.; Cruz, P. L. B.; Cruz, K. L. B.; Teixeira, B. J.; Medina, M. D. P.; Effio, P. J. C.; Pueblo Cont. 2012, 23, 345.

4. Verdan, M. H.; Stefanello, M. E. A.; Chem. Biodiversity 2012, 9, 2701.

5. Verdan, M. H.; Ehrenfried, C. A.; Scharf, D. R.; Cervi, A. C.; Salvador, M. J.; Barison, A.; Stefanello, M. E. A.; Nat. Prod. Commun. 2014, 9, 1535.

6. Verdan, M. H.; Souza, L. M.; Carvalho, J. E.; Costa, D. B. V.; Salvador, M. J.; Barison, A.; Stefanello, M. E. A.; Chem. Biodiversity 2015, 12, 148.

7. Moreira, R. Y.; Arruda, M. S.; Arruda, A. C.; Santos, L. S.; Müller, A. H.; Guilhon, G. M. S. P.; Santos, A. S.; Terezo, E.; Rev. Bras. Farmacogn. 2006, 16, 392.

8. Messana, I.; Sperandei, M.; Multari, G.; Galeffi, C.; MariniBettolo, G. B.; Phytochemistry 1984, 23, 2617.

9. Tian, J.; Zhao, Q.; Zhang, H.; Lin, Z.; Sun, H.; J. Nat. Prod. 1997, 60, 766.

10. Yamamoto, H.; Hori, M.; Kuwajima, H.; Inoue, K.; Planta 2003, 216, 432.
11. APEX2 Version 2014/1-1, Bruker AXS Inc.: Madison, WI, USA, 2014; SAINT Version 8.34A, Bruker AXS Inc.: Madison, WI, USA, 2013.

12. Dolomanov, O. V.; Bourhis, L. J.; Gildea, R. J.; Howard, J. A. K.; Puschmann, H.; J. Appl. Cryst. 2009, 42, 339.

13. Sheldrick, G. M.; Acta Cryst. 2015, A71, 3.

14. Sheldrick, G. M.; Acta Cryst. 2008, A64, 112.

15. Salvador, M. J.; Ferreira, E. O.; Pral, E. M. F.; Alfieri, S. C.; Albuquerque, S.; Ito, I. Y.; Dias, D. A.; Phytomedicine 2002, 9, 566.

16. Verdan, M. H.; Barison, A.; Sá, E. L.; Salvador, M. J.; Poliquesi, C. B.; Eberlin, M. N.; Stefanello, M. E. A.; J. Nat. Prod. 2010, 73, 1434.

17. Scharf, D. R.; Verdan, M. H.; Ribeiro, M. A.; Simionatto, E. L.; Sá, E. L.; Salvador, M. J.; Barison, A.; Stefanello, M. E. A.; J. Nat. Prod. 2016, 79, 792.

Submitted: April 12, 2016

Published online: July 8, 2016

FAPESP has sponsored the publication of this article. 